See discussions, stats, and author profiles for this publication at:

https://www.researchgate.net/publication/265380396

\title{
In Pursuit of Institutional \\ Legitimation: Structuration of an Offshoring Decision
}

Article · September 2014

DOI: $10.1080 / 15228053.2014 .940259$

CITATION

1

1 author:

\section{Rajesh Mirani}

University of Baltimore

28 PUBLICATIONS 550 CITATIONS

SEE PROFILE
READS

37

Some of the authors of this publication are also working on these related projects:

Project (To be Decided) View project

All content following this page was uploaded by Rajesh Mirani on 07 April 2015. 
This article was downloaded by: [University of Baltimore], [Rajesh Mirani]

On: 08 September 2014, At: 11:17

Publisher: Routledge

Informa Ltd Registered in England and Wales Registered Number: 1072954 Registered office: Mortimer House, 37-41 Mortimer Street, London W1T 3J H, UK

Information Technology Case and Application Research

\section{J ournal of Information Technology Case and Application Research}

Publication details, including instructions for authors and subscription information:

http:// www.tandfonline.com/loi/ utca20

\section{In Pursuit of Institutional Legitimation: Structuration of an Offshoring Decision}

\author{
Rajesh Mirani $^{\text {a }}$ \\ aniversity of Baltimore \\ Published online: 03 Sep 2014.
}

To cite this article: Rajesh Mirani (2014) In Pursuit of Institutional Legitimation: Structuration of an Offshoring Decision, J ournal of Information Technology Case and Application Research, 16:2, 70-90, DOI: $10.1080 / 15228053.2014 .940259$

To link to this article: http:// dx. doi.org/10.1080/ 15228053.2014.940259

\section{PLEASE SCROLL DOWN FOR ARTICLE}

Taylor \& Francis makes every effort to ensure the accuracy of all the information (the "Content") contained in the publications on our platform. However, Taylor \& Francis, our agents, and our licensors make no representations or warranties whatsoever as to the accuracy, completeness, or suitability for any purpose of the Content. Any opinions and views expressed in this publication are the opinions and views of the authors, and are not the views of or endorsed by Taylor \& Francis. The accuracy of the Content should not be relied upon and should be independently verified with primary sources of information. Taylor and Francis shall not be liable for any losses, actions, claims, proceedings, demands, costs, expenses, damages, and other liabilities whatsoever or howsoever caused arising directly or indirectly in connection with, in relation to or arising out of the use of the Content.

This article may be used for research, teaching, and private study purposes. Any substantial or systematic reproduction, redistribution, reselling, loan, sub-licensing, systematic supply, or distribution in any form to anyone is expressly forbidden. Terms \& Conditions of access and use can be found at http://www.tandfonline.com/page/termsand-conditions 


\title{
In Pursuit of Institutional Legitimation: Structuration of an Offshoring Decision
}

\author{
Rajesh Mirani \\ University of Baltimore
}

\begin{abstract}
This article applies structuration theory and institutional theory to analyze the organizational dynamics behind a financial services company's decision to initiate information technology services offshoring. The analysis finds the decision to have been an emergent one, crystallizing from interactions between upper management's actions and an evolving structural context. Further, their actions were driven more by a legitimation-oriented desire to adhere to various institutional norms rather than purely rational considerations. These findings of isomorphism question the notion that offshoring decisions result from straightforward objectives such as cost savings or quality enhancement. Particularly under uncertainty, they may be subtly shaped by institutional influences in antecedent contexts. The implication is that the planning, execution, and evaluation of offshored projects must take into account the dynamic imperatives embedded in these contexts, and not be anchored solely to static expressions of short-term or long-term objectives.
\end{abstract}

Information technology (IT) offshoring research in recent years has focused primarily on inter-organizational issues such as task oversight and relationship governance (Alami et al., 2008; Aydin et al., 2010; Cha et al., 2008; Haried \& Ramamurthy, 2010; Kelly \& Noonan, 2008; Leonardi \& Bailey, 2008; Palvia, 2008; Palvia et al., 2011; Ranganathan et al., 2007; Simon et al., 2009). An enduring emphasis on client-vendor interactions has yielded numerous, ongoing insights into offshoring management, resulting in a rapidly evolving set of best practices. In marked contrast to this rich knowledge base on contractual and/or post-contractual processes, the internal mechanisms by which client organizations arrive at initial offshoring decisions are poorly understood. Little attention has been accorded to the pre-contractual context that precedes such a decision, and the dynamics that engender it. This inattention to antecedent processes has perpetuated a nebulous awareness of how client organizations decide to undertake offshoring. As a result, it has left unexplored the influences of upstream processes in the lead up to offshoring decisions, on downstream processes such as those pertaining to articulated offshoring rationales, offshored task selection, and vendor oversight, as well as on overall outcomes. For example, a commonly cited reason for offshoring is the achievement of cost savings. The prevailing viewpoint in this regard is that internal efficiency-oriented goals are best pursued by means of contractual, arms-length relationships with vendors, for highly defined, well-structured tasks.

(C) Rajesh Mirani

Correspondence should be addressed to Rajesh Mirani, Associate Professor, Information Systems \& Decision Science, Merrick School of Business, University of Baltimore, 11 West Mt. Royal Avenue, Baltimore, MD 21201, USA. E-mail: rmirani@ubalt.edu 
However, the suitability of such an approach may vary from one context to another, depending, for instance, on whether the target of cost savings constitutes an organizational response to an environmental threat, or is being pursued as a strategic opportunity instead. Clearer linkages between pre-contractual and post-contractual processes could thus well result in significant changes to currently accepted practices.

The literature compensates for the short shrift given to pre-contractual client processes, by often addressing the outcomes of these processes - the question of why clients offshore IT tasks. It reports that client motivations for offshoring have changed over the years, from largely costbased rationales to more balanced combinations of economic and strategic considerations (Dunn et al., 2009; Gupta et al., 2007; King, 2008; Messner, 2011; Venkatraman, 2004). Other factors reported in the more general context of outsourcing include managerial self-interest (Hall \& Liedtka, 2005; Miranda \& Kim, 2006), and imitative or bandwagon behavior (Blaskovich \& Mintchik, 2011). Regardless, the customary practice in determining offshoring imperatives has been to take client self-reports at face value, with no methodological provisions to systematically look for deeper or concealed motives. Their prima facie acceptance evidently renders irrelevant the context and dynamics in the lead up to the initial offshoring decision. And yet, accounts of disappointing project outcomes continue to appear unabated in the literature, with few discernible patterns or commonalities. Failures and derailed endeavors are often attributable to poor client-vendor communications (e.g., Avison \& Banks, 2008; Kumar et al., 2009), but it should not necessarily be assumed that this is mostly the case, for two reasons. First, it would be risky to rule out other problem sources, such as ambiguities, inconsistencies, poor commitment, internal disagreements, and so on, in client objectives and motives, without scrutiny. Second, such an assumption would lead to even more studies focusing on client-vendor interactions, at the further expense of a better understanding of internal client processes.

This paper attempts to redress some of this neglect, by presenting a case study of a client organization. The context comprises the organizational dynamics preceding the decision to initiate IT offshoring. The analysis sheds light on a longitudinal, multiyear interplay of these dynamics. Factors include the organization's internal and external environments, its technological context, and upper management decisions/actions. The analysis identifies mutual influences among these factors and assesses their role in shaping and reshaping the organizational context. It retraces the iterative process by which an unmistakable imperative to offshore IT emerges from a continually reshaped context, for which no such imperative had previously been perceived. The endpoint of the study is the perceptual awareness of this imperative, and upper management's decision to offshore some IT services for the very first time.

This interplay is presented upon the twin underpinnings of structuration theory and institutional theory. Both are ideally suited for analyzing human agent actions in complex, multi-factor processes. In addition, conceptually compatible paradigms and complementary strengths characterize them (Barley \& Tolbert, 1997). Structuration theory provides an excellent platform for depicting recursive mutual influences, while institutional theory offers a systematic framework for identifying potentially pertinent factors. The application of structuration theory to the case, therefore, illustrates how an organization's offshoring decision may emerge organically from evolving interactions between various antecedent factors. An exposition of the dynamic nature of this process would be invaluable to decision makers considering or reconsidering offshoring. It would enable them to critically assess their ostensible motivations for offshoring, set realistic objectives, and envision consonant, effective governance mechanisms. 
The other theoretical paradigm applied to the case is institutional theory, in order to bring out the potentially important role of institutional-level isomorphic influences in emergent offshoring decisions. The application of this theory is consistent with the broad research agenda suggested by Orlikowski and Barley (2001), specifically, to examine "how institutions influence the design, use, and consequences of technologies" (p. 153). It is also in line with Thompson's recommendation for IS researchers interested in the emergent outcomes of technological systems to supplement the application of structuration theory with noncognitive, psychologically oriented frameworks (Thompson, 2012). Accordingly, a major part of the analysis is structured to highlight upper management's constant endeavor to align their actions and decisions with institutional reference points of legitimation and credibility. It will show that their overall approach along these lines served to successively reshape a purely organizational context with no technological imperatives whatsoever. The altered, emerging context gradually manifested various evolving properties, ultimately including one that had technology implications - a perceived need to initiate IT offshoring.

The primary research question is: Is it possible to analyze an IT offshoring decision in order to obtain a rich understanding of its antecedent processes, by applying a dual theoretic lens that combines structuration theory with institutional theory?

The rest of this article is organized as follows. The second section introduces the two theoretical foundations for the study-structuration theory and institutional theory. The third section, comprising the analytical core of the paper, presents the case study of a financial services organization, together with the case analysis and discussion. The fourth and final section summarizes the implications, and concludes the study.

\section{THEORETICAL FOUNDATIONS}

\section{Structuration Theory}

The theory of structuration is predicated on the supposition of social systems as productions of "social practices" or "transactions between agents" (Giddens, 1976, 1979, 1984). According to this theory, a social system possesses no "structure," but exhibits "structuring properties" such as attributes, such as norms, policies, procedures, and work practices. They represent the system's "rules and resources" that human actors ("agents") employ to "reconstitute" or "reenact" the system. Ongoing agency actions may intentionally or unintentionally reinforce and reproduce the system's structuring properties, or weaken and transform them. Structure and agency action therefore act symbiotically as mutual influences, constantly adjusting and adapting to each other, or perpetuating and reinforcing each other. For example, a certain configuration of policies, procedures, work practices, and culture may generate effective decisions, actions, and outcomes, culminating in a positive feedback loop that validates and strengthens the configuration. Alternatively, it may generate poor decisions, actions, and outcomes, culminating in negative feedback that insubstantiates and weakens it, thereby triggering adaptive agency action to reconstitute a modified configuration. The transformed structure may then interact with agency to spawn new decisions and actions, whose impacts may trigger more adaptive changes, and so on.

The process of structuration of a system entails uncovering systemic paradigms behind such interactions. It is the study of how structuring properties interact with "situated" practices, and 
how their outcomes successively reshape both properties and actions. The theory identifies three types of structuring properties: signification structures, domination structures, and legitimation structures (Giddens, 1979). Signification structures capture ways in which the system encodes information. Domination structures signify mechanisms for authorization and allocation, and linkages between the two. Legitimation structures denote norm-oriented regulations by which "legitimate orders" are maintained and preserved. In interactions with human actors, signification structures reproduce communication and meaning, domination structures reproduce power (interactions involving relative autonomy and dependence), and legitimation structures reproduce sanctions (conformance, exerted through coercion or inducement).

Finally, actors are said to draw upon different "modalities" to interact with each of the three structure types. They are, respectively, interpretative schemes for signification structures, facility for domination structures, and norms for legitimation structures. Interpretative schemes are standardized subsets of common knowledge repertoires for agents to apply in their interactions. Facility is the ability of agents to draw upon domination-oriented, asymmetric resources to get other agents to comply with their intended actions. Norms comprise approved communications and conduct.

The applicability of structuration theory to information systems research has been discussed at length (Allison \& Merali, 2007; Brooks et al., 2008; Chin et al., 1997; Contractor \& Seibold, 1993; Devadoss et al., 2002; DeSanctis \& Poole, 1994; Evans \& Brooks, 2005; George et al., 2008; Gopal et al., 1992; Harrison et al., 2007; Hussain \& Cornelius, 2009; Hussain et al., 2004; Hussenot, 2008; Jones, 1999; Jones \& Karsten, 2008; 2009; Jones et al., 2000, 2004; Nagasundaram \& Bostrom, 1994; Orlikowski, 1992, 2000; Orlikowski \& Robey, 1991; Poole, 2009; Poole \& DeSanctis, 1990; Pozzebon \& Pinsonneault, 2005; Walsham, 2002; Walsham \& Han, 1991; Yates \& Orlikowski, 1992). The most comprehensive effort in this regard is the adaptive structuration theory (AST), formulated expressly to model behaviors in the use of advanced technologies (DeSanctis \& Poole, 1994; Poole \& DeSanctis, 1990). A marked point of departure for AST from the original structuration theory is its notion that advanced technologies possess social structures, in the form of explicit features or implied "spirit." AST has been applied in a number of IS research studies (e.g., Bhattacherjee \& Harris, 2009; Brooks et al., 2008; Chin et al., 1997; Contractor \& Seibold, 1993; Gopal et al., 1992; Hussain et al., 2004; LeRouge \& Webb, 2004; Niederman et al., 2008; Schwieger et al., 2005).

The case analysis reported here uses the original structuration theory rather than AST, for a couple of reasons. First, the context of the present study centers on organizational processes leading up to an IT offshoring decision, rather than the actual implementation or use of any particular technology. Therefore, AST is not quite applicable here. Second, a key aspect of this study entails demonstrating that an organization's external spheres of affiliation often serve as sources of factors or influences that interact to shape its internal context. Institutional theory provides a systematic framework of such spheres, but its tenets are compatible with the original structuration theory, not with AST.

\section{Institutional Theory}

Institutional theory focuses on the enduring attributes of populations or networks, of organizations or parts thereof. Its level of analysis, therefore, is clusters, collectivities, or affiliations-of 
individuals, organizations, or organizational subsets-formal, informal, or perceived. Examples of clusters are industries and segments, loose alliances and trade associations, as well as abstract institutional fields-for example, the IT offshoring field, or, the knowledge management field. The central idea in contemporary institutionalism is that the behavior of a cluster member is significantly influenced by the extent to which it identifies perceptually with the collectivity. Members with greater overall sense of affiliation and belonging are likely to derive more of their behavioral attributes (and structural ones, too, in the case of organizations) from the group, relative to other members.

In recent years, the focus of institutional theory has gradually shifted away from structure and forms towards interactional processes and behavior. This reorientation has brought institutionalism philosophically closer to structuration, in that both theories consider organizational action as a key notion deserving close observation. Neo-institutionalism, the theory's newer incarnation, is oriented to the study of how organizations pursue "legitimacy" in seeking stabilizing sources of influence for their actions. DiMaggio and Powell's seminal work has shown that institutional influences on individual organizations can take three forms - coercive processes, mimetic processes, and normative processes (DiMaggio \& Powell, 1983). Organizations are generally said to be exposed to all three in action contexts, perceiving them as pressures to conform to the collective. These pressures result in an isomorphic trend, whereby member organizations tend to exhibit convergence and collective rationality.

The analysis of the case study presented in Section 3 illustrates the potential key role of isomorphic influences in the IT offshoring decision. It shows how upper-level managers, in interacting with evolving organizational contexts, appeared to be motivated consistently by an apparent need for legitimacy in regards to their decisions and actions. A mutual structuration of context and legitimation-oriented agency action ultimately spawned the conditions to which management responded with the focal decision to initiate IT offshoring.

\section{Complementary Perspectives}

As stated previously, the analysis of the offshoring decision reported herein will utilize a dual theoretic lens that combines structuration theory with institutional theory. These two particular theories were selected for the analysis because while their similarities provide them both with the requisite applicability to decisions of an emergent nature, their differences enable the generation of complementary perspectives, resulting in a richer overall understanding of processes underlying the decisions. For example, both theories are well suited to the examination of social structures behind organizational decisions. In other words, both theories look beyond the limited view of decision makers as purely "rational" actors. However, they approach this task from different angles. Structuration theory focuses on how interactions between agency (i.e., managers) and the organization's own structuring properties shape such decisions. It is therefore internally oriented, with the organization as its level of analysis. On the other hand, institutional theory addresses how decisions may be subject to influences from institutions other than the organization itself. This accords it more of an extra-organizational orientation, but with the simultaneous recognition that institutional influences may occur at either the individual level, the organizational level, or the inter-organizational level. A combination of both theoretical perspectives, therefore, would cover greater ground in terms of possible factors at work than what may be covered by 
either theory alone. Likewise, both theories address organizational change, but they do so in rather contrasting ways. Structuration theory is especially well placed to explain the nature of gradual change, while contemporary institutional theory is more oriented towards showing how the need for institutional legitimacy is a frequent impediment to change. Thus, structuration is capable of explaining how structures may be sustained by routine, but institutionalism underscores how norms sustain them. Again, the combined application of both perspectives holds the promise of a more complete and accurate picture of how opposing forces play out in the form of emergent decisions. Lastly, both theories provide ample room for long-term changes to decision contexts, but in very different ways. According to structuration, it is possible for the structuring properties of a given context to be gradually weakened by agency-structure interactions to the point where they may be reconstituted in different configurations. Conversely, institutionalism recognizes the possibility of changes to the influencing context through the notion of deinstitutionalization, or, the gradual erosion of institutionalized activities. Once again, the congruence of these two diverse perspectives translates into better collective insights into offshoring decisional processes than what is possible with either theory by itself.

Table 1 summarizes the complementary perspectives provided by the two theories.

These complementary perspectives comprise the basis for the structure of the dual theoretic lens that will be applied to the case study reported in the paper. In keeping with the strengths of both structuration theory and institutional theory, the lens will focus on the social structures behind the offshoring decision. To accomplish this, key agency actions in the antecedent context of the decision will first be identified. Next, each such agency action will be analyzed for agent interactions with structuring properties. While the analyses of these interactions are in accordance with structuration theory, the unique blended approach followed here will be to explicitly look for evidence of isomorphism or institutional convergence in the interactions

TABLE 1

Complementary Perspectives of Structuration Theory and Institutional Theory

\begin{tabular}{|c|c|c|}
\hline (Attribute) (Theory) & Structuration Theory & Institutional Theory \\
\hline Focus & Organizations as social structures & Institutions as social structures \\
\hline Scope & Organizational & Organizational; extra-organizational \\
\hline Level of Analysis & Organization & Organization \\
\hline Purpose of Theory & Explain organizational change & Explain organizational resistance to change \\
\hline Role of Rationality & $\begin{array}{l}\text { Decision makers as non-rational } \\
\text { actors }\end{array}$ & Decision makers as non-rational actors \\
\hline Independent Construct(s) & $\begin{array}{l}\text { Internal agency; internal } \\
\text { structuring properties }\end{array}$ & $\begin{array}{l}\text { Institutional influences at three levels-individual, } \\
\text { organizational, inter-organizational }\end{array}$ \\
\hline Dependent Construct & Organizational change & Resistance to organizational change \\
\hline Change Drivers/Barriers & $\begin{array}{l}\text { Recursive interactions between } \\
\text { agency and structure }\end{array}$ & Need for institutional legitimacy \\
\hline Change Mechanisms & $\begin{array}{l}\text { Recursive interactions can } \\
\text { reinforce or weaken structure }\end{array}$ & $\begin{array}{l}\text { Institutional pressure can reinforce or weaken } \\
\text { norms }\end{array}$ \\
\hline $\begin{array}{l}\text { How Social Structures Are } \\
\text { Sustained }\end{array}$ & By routine & By norms \\
\hline $\begin{array}{l}\text { Long-Term Changes to } \\
\text { Decision Contexts }\end{array}$ & $\begin{array}{l}\text { Weakened and reconstituted } \\
\text { structuring properties }\end{array}$ & Deinstitutionalization \\
\hline
\end{tabular}


and/or their outcomes. Outcomes examined will include both reconstituted structures as well as reconstituted contexts. Lastly, any isomorphic interactions uncovered in this manner will be subjected to additional scrutiny from the decision-making literature in order to validate the claims of isomorphism.

\section{THE CASE STUDY}

This section applies the dual theoretic lens as outlined above to the case study of a financial services provider. A description of the research method is followed by an overview of the company. Next, the case context is presented in narrative form, with an emphasis on agency, specifically, upper management's decisions and actions. The context spans a period of several decades, beginning with conditions of high profitability and environmental stability, and ending with the company's decision in the mid-2000s to offshore some IT services. Finally, agencycontext interactions in this articulated context are analyzed systematically for insights. This kind of longitudinal analysis conforms well to the structuration theory's stipulation of agency actions as "continuous flow of conduct" (Giddens, 1979, p. 55).

\section{Research Method}

The data reported in this study comprise roughly $50 \%$ of a broader research initiative undertaken to investigate both the antecedents and consequences of the offshoring decision reported here. While the antecedents of that decision are the focus of this particular paper, its consequences have been reported elsewhere (Mirani, 2013). Data were gathered by conducting detailed, recorded interviews with managers who had participated in the company's offshoring decision and/or had close knowledge of its intricacies. The job titles of these managers were, respectively, Chief Technology Officer-Asia-Pacific, Director of Product Development Technology, Senior Vice President of Development and Support, and Assistant Vice President of Development. Each manager had more than 10 years of work experience. The total amount of time spent on their interviews added up to approximately 25 hours.

The audio files resulting from the recorded interviews were first translated into written transcripts. Next, these transcripts were subjected to systematic content analysis, with the objective of uncovering major themes, patterns, trends, and progressions pertinent to the study's research question. Structured encoding schemes were employed to document all of these, with key words and phrases from interviews serving as supporting evidence. Finally, the two theoretical frameworks adopted for the study were applied to this analysis, in order to generate more meaningful, substantive interpretations.

\section{The Company}

Tradeamity (a fictitious name for a real organization) is a leading global provider of innovative products and services related to business information. Headquartered in the United States, it derives most of its revenues from its North American operations. It also conducts major operations in several countries across Europe, the Asia-Pacific region, and South America, through 
decentralized, country-specific units for sales, support, and fulfillment. It has maintained a strong presence in this business-to-business industry segment over many decades of its existence. Historically, its main products have been research-based, customized information reports that provide quantitatively oriented assessments of how diligently specific businesses pay their bills. Typical customers have been finance managers or upper-level managers looking to gauge the solvency of potential business partners, or the viability of inter-organizational alliances. Competing products in this space include information available through credit bureaus, customer relationship management (CRM) offerings for customers to conduct their own analyses, and credit card companies such as American Express. Tradeamity has grown to offer a wide range of products to a broader spectrum of customers, but the essence of these products and the company's core competence has remained remarkably constant. Worldwide, annual sales amount to more than $\$ 1$ billion. As Tradeamity's products basically comprise information, its IT function has always played a very important role. The company's IT budget now comprises roughly a quarter of total corporate spending.

\section{The Context}

Tradeamity's unique business information products and services had carved out a completely new industry, according the company a monopoly-like status from the very outset. Over time, its core product, the business information report, came to be used so widely that it was considered the industry standard. A near exalted status for its brand enabled the company to enjoy a long period of unchallenged market growth in a stable, benevolent environment. Lulled by decades of industry stability, upper management had adopted a laissez faire attitude, characterized by an ad hoc approach to issues.

Across the company, the overarching emphasis had long been on "top line" growth, with little concern for bottom line improvements, such as through cross-segment information sharing efficiencies. A visible manifestation of this easygoing philosophy was the enormous latitude given to sales teams in negotiating various aspects of customer contracts, ranging from pricing structures and information product formats to content reuse, as long as business volume continued to increase steadily. The freedom and flexibility to structure contracts in any manner resulted in the propagation of inconsistent contractual terms, pricing schemes, concessions offered, and product attributes.

Eventually, Tradeamity's U.S. operations came to be characterized by a decentralized architecture, in which each customer segment was supported by separate sales, fulfillment, support, and training units. Their cascading impacts led to overlapping product lines and redundant service units, within and across customer segments. All of this greatly increased overall operational complexity and total costs. Despite this increase, the company maintained profitability, given its near monopoly status, and a carefully nurtured aura of conservativeness and impartiality, deemed vital for a financial services market leader.

In striking contrast to the carefully inculcated market image, however, management went to extreme lengths to keep a low public profile for the company, including a custom of not having the company's name or logo displayed on the exterior walls of its own buildings. These measures 
were designed as risk-avoidance mechanisms intended to discourage negative publicity, market speculation, and takeover attempts, given the company's long profitability record.

After many consecutive years of double-digit growth, Tradeamity started to experience market saturation. By this time, niche competitors had also emerged and strengthened on multiple fronts, weakening the company's exclusive hold. Fearing an impending commoditization of its core product, the business information report, the management team preemptively tapped into company's surplus capital reserves from its halcyon years to make a series of corporate acquisitions. However, the acquired businesses had little in common with the company's core competencies. As a prolonged economic recession set in soon afterwards, many of the new businesses failed, causing the acquisitions strategy to backfire. For the first time in its history, Tradeamity's bottom line was seriously threatened.

Management responded to this new exigency on three fronts. First, it applied drastic costcutting pressures on product lines, departments, and individual employees, and downsized the organization. Concurrently, it started to divest from unrelated businesses, with the intent of paring down the existing product lines into a smaller, more compact set. It also came up with a longterm plan to redesign the company's remaining product/service portfolio. As a result of these measures, Tradeamity continued to be profitable, but barely so.

In its commitment to cut costs, management started looking for ways to lower product "fulfillment" expenses-the design and delivery costs of information reports. It found that this could be accomplished in two ways. On the business side, it was possible to generate synergies from Tradeamity's information base, by the repeated use of common data sets. That is, base data could be leveraged to create multiple information views and analyses tailored to individual customers. On the technology side, more automation could be employed in order to enhance the efficiency and effectiveness of data collection, validation, storage, and dissemination.

The implementation of these initiatives led to two unanticipated developments. First, its new homegrown automation techniques were so successful that Tradeamity patented them, subsequently converting some into new product lines. Second, management realized that the key to successfully leveraging information synergies was the labor costs of technology. After considering various options in this regard, it arrived at the decision to offshore some IT services, with the overall objective of lowered product development costs.

\section{Analysis Using Dual Theoretic Lens}

Salient agency actions in the expanded context above will now be analyzed, in terms of upper management's interactions with various structuring properties. Collectively, these interactions will comprise a complete picture of the structuration process. Each interaction will also be analyzed for evidence of isomorphism, or institutional convergence, in agent actions. Further, since agent-structure interactions are said to not only shape the structuration process but also reconstitute the context, the analysis of each interaction will address both types of outcomes. Lastly, whenever a particular interaction appears to exhibit isomorphic qualities, alternative courses of action not pursued by agents will be presented, in order to validate the isomorphism assertion.

A summary of the structured analysis that follows is provided in Table 2 . The discussion below is organized by one row at a time--Rows A, B, C, and D. 


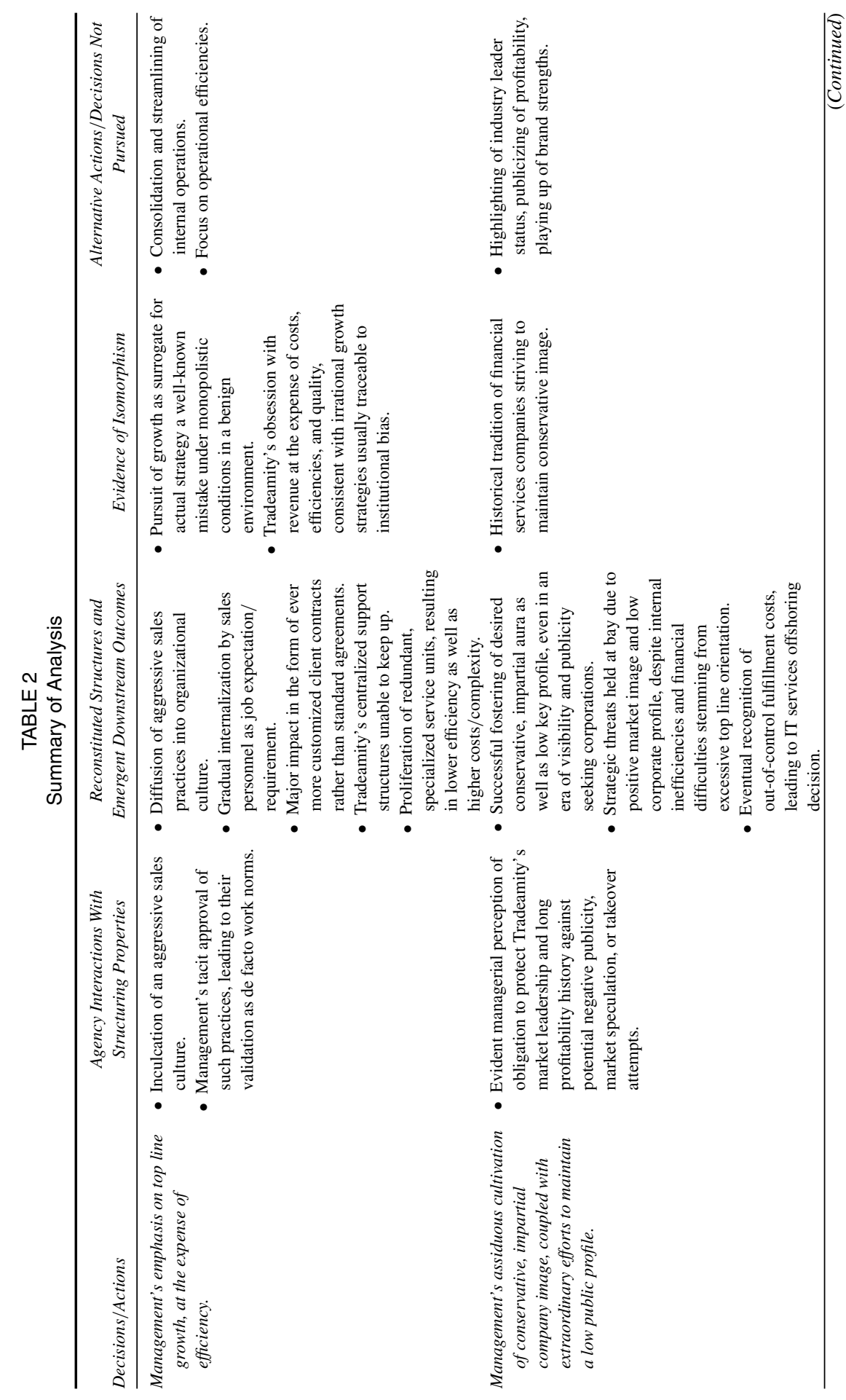




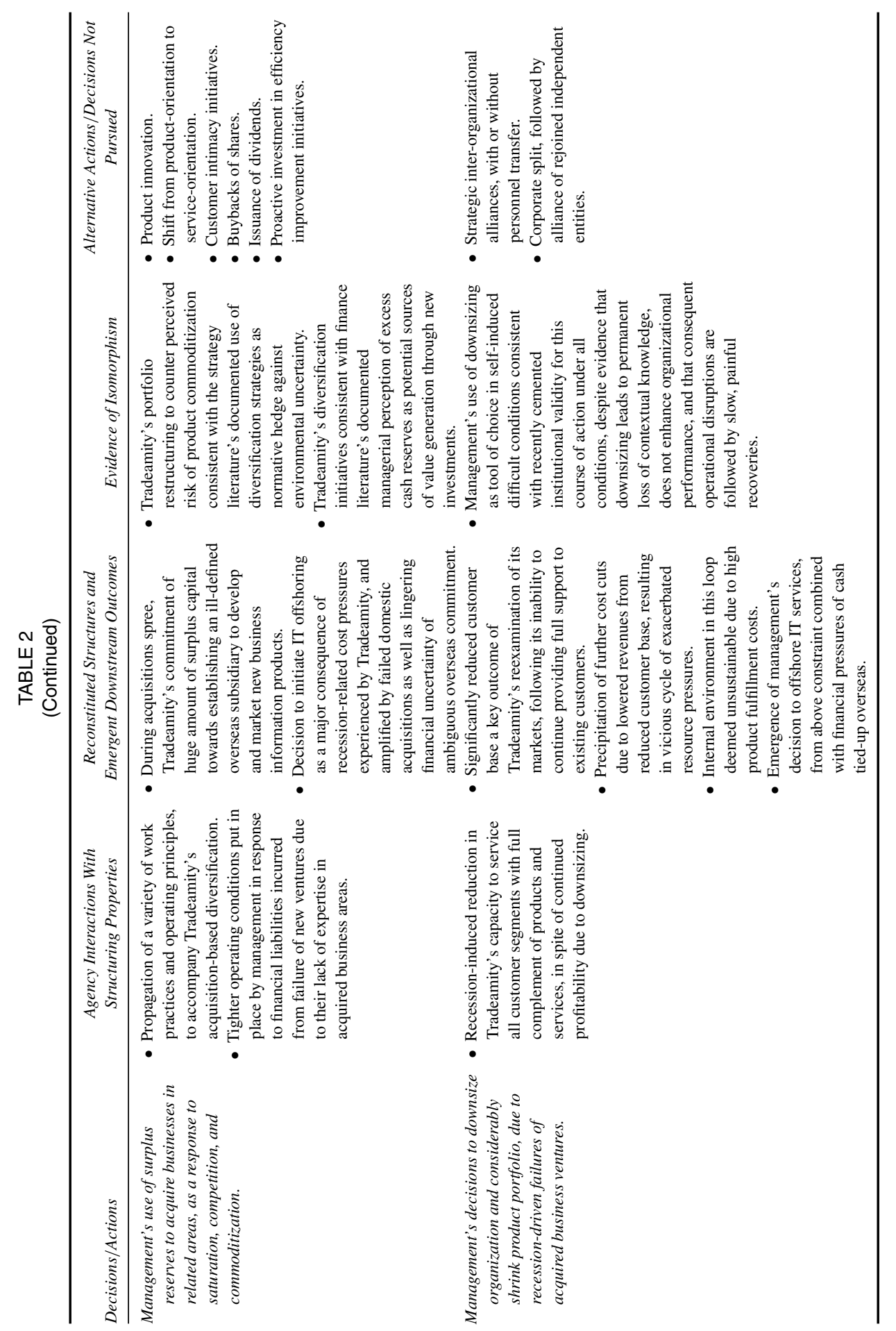


A. Agent Actions/Decisions: Management emphasized top line growth at the expense of efficiency.

- Agency interactions with structuring properties: The use of top line growth measures to assess individual performance inculcated an aggressive sales culture that was tolerated and even encouraged by management. Their tacit approval of such practices served to validate them as de facto work norms.

- Reconstituted structures and emergent downstream outcomes: The diffusion of aggressive sales practices into the organizational culture caused it to be internalized by sales personnel as a job expectation/requirement. They acted by pushing the envelope into the domain of contractual negotiations with clients. The result was an increasing number of exceptions to standard agreements, followed by exceptions becoming the norm. Customized contracts proliferated, comprising a variety of product attributes, pricing schemes, and concessions offered. The company's standard support structures struggled to meet all these disparate terms. In response, multiple, overlapping product lines, as well as redundant, specialized service units sprang up throughout the organization. The undesired effects of these new structures were lowered overall efficiency, and increased operational costs and complexity.

- Evidence of isomorphism: Market leaders in competitive and turbulent conditions tend to focus on innovation and customer networks (Chakravarthy, 1997; Felisberto, 2012). However, as a monopolistic player in a benign environment, Tradeamity had no real competition. Under such conditions, organizations have been known to mistakenly pursue growth as a substitute for actual strategy, even given little industry room for growth (Porter, 1996). The literature also identifies institutional biases as sources of "irrational growth" strategies - those unlikely to translate into profitability (Voelker, 2011). Tradeamity's fixation on revenue, and concomitant neglect of cost structures, process efficiencies, or product quality, was consistent with these norms.

- Alternative actions/decisions not pursued: As the dominant market player, there were no urgent imperatives for upper management to aggressively pursue further top line growth, particularly at the expense of operational efficiencies. A more rational course of action would have been to consolidate and streamline internal operations (Porter, 1996). This option was even available after the implementation of aggressive sales strategies had caused operational costs and complexity to go up. However, upper management did not do so until external exigencies forced their hand, choosing instead to extrapolate and perpetuate the company's past orientations and postures for as long as possible (Miller \& Friesen, 1978).

B. Agent Actions/Decisions: Management cultivated a conservative, impartial image of the company, and went to extreme lengths to keep a low public profile.

- Agency interactions with structuring properties: Upper management's intent was to protect Tradeamity's leadership position and long history of profitability against potential threats that might possibly emanate from the public, the government, or acquisition-minded organizations. Their assiduous cultivation of a low profile for the company constituted risk avoidance mechanisms in order to minimize the possibility of negative publicity, market speculation, or takeover attempts.

- Reconstituted structures and emergent downstream outcomes: Minimizing the public's attention to itself in an era of corporate visibility and publicity helped Tradeamity hold 
on to the conservative, impartial aura it had fostered. However, management may also have looked upon the need for a conservative image as a strategic burden or constraint that smaller players and emerging competitors were not necessarily encumbered with. This interpretation is consistent with the company's excessive wariness of upstarts, and obsessive focus on market share, particularly given its comfortable, monopolistic industry position. There were many consequences of this top line orientation. These included internal inefficiencies, difficulties in coping with an economic downturn, and, eventually, the decision to offshore IT services in order to lower fulfillment costs.

- Evidence of isomorphism: Striving to maintain a conservative image is a historical tradition for financial services companies (Uzelac \& Sudarevic, 2006). Upper management's efforts in this regard were therefore in line with this norm. Further, in weighing the merits of physical anonymity against those of a bold corporate presence, management evidently perceived the need to preserve the company's conservative aura as being more consistent with a low public profile.

- Alternative actions/decisions not pursued: Tradeamity could have protected and perpetuated its industry leadership position by highlighting this status as well as its marketplace image, publicizing its profitability, and playing up its brand strengths. Aside from countering nascent rivals, this would have also have served as a starting point for Tradeamity to plan out more meaningful strategic directions. Any takeover attempts or speculative trading of the company's stocks from the enhanced visibility would have forced the company to turn its focus inward on internal consolidation and operating efficiencies, something that it needed to do anyway. Being better placed to weather the adverse economic conditions it would encounter later may also have obviated the need to offshore IT services.

C. Agent Actions/Decisions: In response to market saturation, tougher competition, and the possibility of product commoditization, management tapped into the company's surplus capital reserves to acquire several businesses unrelated to Tradeamity's core competencies.

- Agency interactions with structuring properties: Tradeamity's acquisitions created a diversified organization, with the attendant complexities of a variety of work practices and operating principles. Upper management's lack of expertise in these new business areas caused the acquired ventures to fail, creating serious financial liabilities. These unanticipated failures led management to institute tighter operating conditions, whose effects amplified the recession-related cost pressures experienced later by the company.

- Reconstituted structures and emergent downstream outcomes: During the time of its acquisitions initiatives, upper management had also committed a significant chunk of its surplus capital towards an ambitious overseas venture. Its general intent behind this venture was to establish a foreign subsidiary for developing and marketing new business information products. The venture's precise nature and structure, together with a profit repatriation agreement, were in the process of being slowly worked out in intricate negotiations with the governmental bureaucracy. The lingering uncertainty of this financial commitment was to become a major factor in management's subsequent decision to initiate IT offshoring.

- Evidence of isomorphism: The use of diversification strategies as a normative hedge against environmental uncertainty is well documented in the strategy literature (e.g., Bergh \& Lawless, 1998). In acquiring several unrelated businesses, Tradeamity restructured its portfolio to counter a perceived risk of product commoditization. In addition, the financial 
literature offers the insight that managers perceive excess cash reserves as potential sources of value generation through new investment opportunities (Jandik \& Makhija, 2005). Tradeamity's pursuit of diversification by tapping into its surplus capital was therefore fully consistent with normative practices of both institutional fields.

- Alternative actions/decisions not pursued: To counter product commoditization, some alternatives to Tradeamity's preferred acquisitions/diversification response might have included new product innovation (Bowonder et al., 2010), a shift from product-orientation to serviceorientation (Sawhney et al., 2004), and/or customer intimacy (Mascarenhas et al., 2006). As far as utilizing surplus cash reserves, Tradeamity could have opted for share buybacks or dividends instead of corporate acquisitions and overseas ventures (Grullon \& Michaely, 2002). In hindsight, either of these alternatives would have been safer courses of action. Yet another option would have been a proactive investment in efficiency improvement initiatives, to ensure the company's continued market standing in the event of the external environment turning hostile (Porter, 1996). The latter approach would have also been more consistent with the ultra-conservative philosophy manifested in the company's other actions.

D. Agent Actions/Decisions: When Tradeamity's business acquisitions failed due to an economic recession, management downsized the organization and drastically shrank its product portfolio.

- Agency interactions with structuring properties: Downsizing ensured continuing profitability in the face of a recession, but it reduced Tradeamity's capacity to service all customer segments with a full complement of products and services.

- Reconstituted structures and emergent downstream outcomes: A downsized Tradeamity's inability to continue supporting its full product and service portfolio necessitated a reexamination of its markets. The key outcome of that analysis was a significantly reduced customer base, which precipitated further cost cuts, thus reinforcing existing resource pressures. The internal environment that emerged from this loop was deemed unsustainable due to high costs of product fulfillment. This constraint, coupled with the fact that Tradeamity had significant cash tied up overseas, directly led to management's decision to offshore IT services.

- Evidence of isomorphism: The institutional fields of organizational change, strategic management and strategic human resource management provide evidence that downsizing does not enhance organizational performance (Cascio, et al., 1997; Chadwick et al., 2004; ChengFei \& Yu-Fang, 2008; Guthrie \& Datta, 2008; Sitlington \& Marshall, 2011; Wilkinson, 2005). Moreover, recoveries from operational disruptions caused by downsizing often turn into slow, painful processes (De Meuse et al., 2004; Mirabal \& DeYoung, 2005). Even so, a changing managerial ethos has elevated downsizing's status from that of a preferred tool or tactic to an institutionalized action considered valid under almost any conditions (Budros, 1997; Gandolfi 2008; McKinley et al., 2000). Tradeamity's actions were consistent with this normative position, suggesting management's preference for decisions that would be readily perceived as possessing institutional legitimacy. A broader convergence with cost-cutting norms was also evident in the company's tame decision to shrink its product portfolio, rather than to protect its long-standing industry leadership by means of bold, new value propositions for its customers. 
- Alternative actions/decisions not pursued: Downsizing often causes contextual knowledge to be permanently lost. Since such knowledge can only be acquired experientially, some downsized organizations never quite fully regain it. As such, creative alternatives to downsizing need to be considered. One alternative is to establish strategic interorganizational alliances, with or without personnel transfer (Chung et al., 2006). Another may be a corporate split, followed by a rejoining of the independent entities in an alliance, in order to preserve overall operational integrity yet enable individual units to tap into the split's structural benefits. With careful planning, either alternative may yield positive outcomes. In normative terms, though, downsizing beats both alternatives hands down, with its advantages of precedent, recognition, and overall credibility. It was this path of least resistance that upper management chose to follow, in an acknowledgement of its legitimacy.

- The major alternative to a reduced product portfolio would have been new, creative value propositions for the market. One option was a move up the information value chain, away from basic information and statistics towards advanced analysis and interpretation, and evaluation services (e.g., Firestone, 2005). Another was a structural transformation from static information reports to real-time business intelligence, possibly delivered by subscription. Although Tradeamity did gradually venture into some such directions, these were not its initial or primary responses. Also, its product reconfiguration impetus was reactive rather than proactive.

\section{CONCLUSIONS}

The essence of the research question for this study was to determine whether it is possible to obtain a rich understanding of an IT offshoring decision, by analyzing it using a dual theoretic lens combining structuration theory with institutional theory. The results have clearly demonstrated that it is possible to do so, and that such a lens is capable of generating unique insights into the offshoring decision. An analysis has revealed that Tradeamity's decision to initiate IT offshoring crystallized gradually from interactions between upper management's actions and the structuring properties of a constantly evolving context. Two aspects of this are particularly noteworthy.

First, the process was inherently unpredictable in nature. Although upper management's actions represented conscious, deliberate intent in each instance, their interactions with structural elements of the evolving context yielded both expected consequences as well as unanticipated ones. Unexpected intermediate outcomes at various stages in this process comprised a mix of opportunities and crises, but both types significantly altered the context, driving more upper management actions, and so on, in cycles of mutual interdependence. The focal consequence of this progression - upper management's decision to initiate IT offshoring — was an unpredictable development. Its emergence provides a contrarian challenge to the popular view of offshoring decisions as outcomes of planned, structured problem solving processes, driven rationally and deterministically by static, given objectives such as cost savings or quality enhancement. In reality, as the case study shows, the objectives and/or the decision may emerge unexpectedly from intricate influences among complex antecedent processes. Further, these processes and influences are not necessarily restricted to the immediate or broader technology context. Sometimes, organizational culture, management philosophy and style, and/or environmental factors play the more important role. 
Secondly, in their decisions and actions, upper management relied extensively, almost exclusively, on legitimation structures to guide them. This indicates a culture characterized by a high degree of "normative embeddedness" to the institutional context, a trait considered a key source of organizational resistance to change (Greenwood \& Hinings, 1996). It is also consistent with Tradeamity's overall approach to events. Occasionally, upper management appeared to shy away from institutional norms and rationally tap into resources instead-interacting with authorization structures, for example, in Tradeamity's acquisitions, and with allocation structures, in slashing budgets. However, even in interacting with these domination structures to exercise their power, they could only come up with actions evidently sanctioned by precedent. It appears, therefore, that their view of legitimation structures was not just that of repositories of responses to assorted problem contexts, but even as overarching benchmarks against which potential solutions offered by domination structures might be evaluated. These findings seem to extend those of Jain et al. (2008), who note that imitative behavior helps firms in offshoring arrangements in two different ways. First, it counters the uncertainties associated with large geographical distances, by providing legitimation for their actions. Second, it narrows the range of uncertainty by providing them with information cues.

More generally, the findings of the analysis support Orlikowski's practice-oriented perspective of technology (Orlikowski, 2000), a point of view endorsed elsewhere (Jones \& Karsten, 2008). Both have argued against the claim of technological systems as being constrained by their "embedded" structures, and therefore restricted in the range of their possible implementation outcomes. The practice-oriented perspective aligns well with structuration theory's summary caution against such deterministic treatment of technology (Giddens, 1984). It offers the counterargument that technological contexts, despite their material, symbolic, and purposive aspects, do not "embody" structures, and are therefore not static, constraining, or subject to "appropriation." Rather, technology's structural properties, in design, implementation, and use, are "emergent" or enacted, through ongoing, recursive interactions with actions of agents, such as users and decision-makers.

\section{IMPLICATIONS FOR PRACTICE AND RESEARCH}

For practitioners-both general managers and information systems managers participating in initial offshoring decisions-the key implication is that the planning, design, and execution of offshored projects must take into consideration not just static expressions of project objectives, but also the relevant broader contexts and imperatives underlying them. The case study itself illustrates this point. Tradeamity's stated objective in initiating offshoring was to lower its product fulfillment costs. A logical implication of this static view of the decision would be for the company to set up contractual arrangements with an independent, low end offshore vendor, to whom it could hand off most product fulfillment tasks. However, a review of the decision's antecedent processes brings out other pertinent facts—namely, that Tradeamity's business was critically dependent on its information intensive products and homegrown, patented techniques, that Tradeamity had significant funds tied up in a country known for its IT offshoring industry, 
and that it had committed these funds to an undefined venture there. This additional, contextual information introduced a new possibility — that of setting up an offshoring subsidiary in that country using the tied-up funds, with Tradeamity as the subsidiary's first customer. This approach would help the company three ways. It would resolve the overseas funds dilemma, achieve the objective of lower product fulfillment costs without loss of control over proprietary IT applications, as well as mesh with Tradeamity's intent to redesign its market portfolio. In the long run, the subsidiary might even come up with new information solutions, evolving from a low cost producer to an innovation center. However, none of this would be at all possible without a holistic view of the decision, including a cognizance of its antecedent contexts. A key takeaway for practitioners, therefore, is the awareness that organizational factors unrelated to technology can easily be the major driving forces behind IT offshoring decisions.

For researchers, one set of implications follows from the finding that legitimation structures played a key role in Tradeamity's offshoring decision. An obvious research question to pursue is whether this is also true of offshoring decisions in other organizations. If not, then a logical follow-up would be to look for contextual patterns that might help explain why legitimation structures are important to this decision in some organizations but not as important in others. A related question is whether agency's engagement with domination structures and signification structures would be more apparent if investigated at a more granular level. In the Tradeamity case, for example, while upper management's actions conveyed the impression of being anchored to norms even for figuring out how to exercise their power and authority, this does not rule out the possibility that they had already reviewed the available domination structures before designating normative structures as their overarching criteria. The study of such highly granular processes, however, would necessitate the use of entirely different data collection techniques, such as a protocol analysis.

A second direction for follow-up research entails examining the relative importance of the organizational and technology contexts. In Tradeamity's case, the organizational context appeared to play the more dominant role relative to the technology context, as upper management interactions were primarily with the former. Attributes that may have influenced this are the high information intensity of the organization's products and services, together with the relative simplicity of actual information processing entailed in their production. Other attributes may include elements of the organizational culture and external environment. One research possibility, therefore, is to look for specific attributes that may cause either the organizational context or the technology context to play the predominant role. A related question is whether this depends less on organizational attributes and more on the functional affiliations of agents. Thus, an example of a testable proposition would be the statement that decisions are more likely to be shaped by the organizational context when decision makers are upper level managers, but by the technology context instead when decision makers are IT managers.

Finally, follow-up research may also test this study's claim that offshored projects will likely yield better outcomes if antecedent contexts are taken into account in project planning and execution. While it would be easy to operationalize outcomes by using surrogates such as product quality, project time/cost overruns, and client satisfaction, for example, the measurement of how well antecedent contexts were incorporated into a project's planning and execution would represent a much bigger challenge. 


\section{CONTRIBUTOR}

Rajesh Mirani is an Associate Professor of Information Systems at the Merrick School of Business, University of Baltimore. His current research interests include the management of offshoring initiatives, and public policy implications of infrastructural IT projects. Dr. Mirani has published in a variety of information systems journals, including recent and forthcoming papers in the International Journal of Information Management, ACM Transactions on Management Information Systems, and the Journal of Organizational Computing and Electronic Commerce. He holds a Ph.D. from the University of Pittsburgh.

\section{REFERENCES}

Alami, A., Wong, B., \& McBride, T. (2008). Relationship issues in global software development enterprises. Journal of Global Information Technology Management, 11(1), 49-68.

Allison, I., \& Merali, Y. (2007). Software process improvement as emergent change: A structurational analysis. Information \& Software Technology, 49(6), 668-681.

Avison, D., \& Banks, P. (2008). Cross-cultural (mis)communication in IS offshoring: Understanding through conversation analysis. Journal of Information Technology, 23(4), 249-268.

Aydin, M. N., de Groot, J., \& van Hillegersberg, J. (2010). Action readiness and mindset for IT offshoring. Journal of Enterprise Information Management, 23(3), 326-349.

Barley, S., \& Tolbert, P. (1997). Institutionalization and structuration: Studying the links between action and institution. Organization Studies, 18(1), 93-117.

Bergh, D., \& Lawless, M. (1998). Portfolio restructuring and limits to hierarchical governance: The effects of environmental uncertainty and diversification strategy. Organization Science, 9(1), 87-102.

Bhattacherjee, A., \& Harris, M. (2009). Individual adaptation of information technology. Journal of Computer Information Systems, 50(1), 37-45.

Blaskovich, J., \& Mintchik, N. (2011). Accounting executives and IT outsourcing recommendations: An experimental study of the effect of CIO skills and institutional isomorphism. Journal of Information Technology, 26(2), 139-152.

Bowonder, B., Dambal, A., Kumar, S., \& Shirodkar, A. (2010). Innovation strategies for creating competitive advantage. Research Technology Management, 53(3), 19-32.

Brooks, L., Atkinson, C. \& Wainwright, D. (2008). Adapting structuration theory to understand the role of reflexivity: Problematization, clinical audit and information systems. International Journal of Information Management, 28(6), 453-460.

Budros, A. (1997). The new capitalism and organizational rationality: The adoption of downsizing programs, 1979-1994. Social Forces, 76(1), 229-250.

Cascio, W., Young, C., \& Morris, J. (1997). Financial consequences of employment-change decisions in major U.S. corporations. Academy of Management Journal, 40(5), 1175-1189.

Cha, H., Pingry, D., \& Thatcher, M. (2008). Managing the knowledge supply chain: An organizational learning model of information technology offshore outsourcing. MIS Quarterly, 32(2), 281-306.

Chadwick, C., Hunter, L., \& Walston, S. (2004). Effects of downsizing practices on the performance of hospitals. Strategic Management Journal, 25(5), 405-427.

Chakravarthy, B. (1997). A new strategy framework for coping with turbulence. MIT Sloan Management Review, 38(2), 69-82.

Cheng-Fei, T., \& Yu-Fang, Y. (2008). A model to explore the mystery between organizations downsizing strategies and firm performance. Journal of Organizational Change Management, 21(3), 367-384.

Chin, W., Gopal, A. and Salisbury, W. (1997). Advancing the theory of adaptive structuration: The development of a scale to measure faithfulness of appropriation. Information Systems Research, 8(4), 342-367.

Chung, Q., Luo, W., \& Wagner, W. (2006). Strategic alliance of small firms in knowledge industries: A management consulting perspective. Business Process Management Journal, 12(2), 206-233.

Contractor, N., \& Seibold, D. (1993). Theoretical frameworks for the study of structuring processes in group decision support systems: Adaptive structuration theory and self-organizing systems theory. Human Communication Research, 19(4), 528-563. 
De Meuse, K., Bergmann, T., Vanderheiden, P., \& Roraff, C. (2004). New evidence regarding organizational downsizing and a firm's financial performance: A long-term analysis. Journal of Managerial Issues, 16(2), 155-177.

DeSanctis, G., \& Poole, M. (1994). Capturing the complexity in advanced technology use: Adaptive structuration theory. Organization Science, 5(2), 121-147.

Devadoss, P., Pan, S. \& Huang, J. (2002). Structurational analysis of e-government initiatives: A case study of SCO. Decision Support Systems, 34(3), 253-269.

DiMaggio, P., \& Powell, W. (1983). The iron cage revisited: Institutional isomorphism and collective rationality in organizational fields. American Sociological Review, 4(2), 147-160.

Dunn, K., Kohlbeck, M., \& Magilke, M. (2009). Future profitability, operating cash flows, and market valuations associated with offshoring arrangements of technology jobs. Journal of Information Systems, 23(2), 25-47.

Evans, J., \& Brooks, L. (2005). Understanding collaboration using new technologies: A structurational perspective. Information Society, 21(3), 215-220.

Felisberto, C. (2012). The relationship between competition and incumbents innovation. Journal of Industry, Competition and Trade, 12(1), 21-46.

Firestone, J. (2005). Mining for information gold. Information Management Journal, 39(5), 47-52.

Gandolfi, F. (2008). Reflecting on downsizing: What have managers learned? S.A.M. Advanced Management Journal, 73(2), 46-55.

George, G., Kotha, R., \& Zheng, Y. (2008). Entry into insular domains: A longitudinal study of knowledge structuration and innovation in biotechnology firms. Journal of Management Studies, 45(8), 1448-1474.

Giddens, A. (1976). New rules of sociological method: A positive critique of interpretative sociologies. London, UK: Hutchinson.

Giddens, A. (1979). Central problems in social theory: Action, structure, and contradiction in social analysis. Berkeley, CA: University of California Press.

Giddens, A. (1984). The constitution of society: Outline of the theory of structuration. Berkeley, CA: University of California Press.

Gopal, A., Bostrom, R., \& Chin, W. (1992). Applying adaptive structuration theory to investigate the process of group support systems use. Journal of Management Information Systems, 9(3), 45-69.

Greenwood, R., \& Hinings, C. (1996). Understanding radical organizational change: Bringing together the old and the new institutionalism. Academy of Management Review, 21(4), 1022-1054.

Grullon, G., \& Michaely, R. (2002). Dividends, share repurchases, and the substitution hypothesis. Journal of Finance, 57(4), 1649-1684.

Gupta, A., Seshasai, S., Mukherji, S., \& Ganguly, A. (2007). Offshoring: The transition from economic drivers toward strategic global partnership and 24-hour knowledge factory. Journal of Electronic Commerce in Organizations, 5(2), $1-23$.

Guthrie, J., \& Datta, D. (2008). Dumb and dumber: The impact of downsizing on firm performance as moderated by industry conditions. Organization Science, 19(1), 108-123, 185.

Hall, J., \& Liedtka, S. (2005). Financial performance, CEO compensation, and large-scale information technology outsourcing decisions. Journal of Management Information Systems, 22(1), 193-221.

Haried, P., \& Ramamurthy, K. (2010). Lessons learned from offshore IT outsourcing: A client and vendor perspective. Journal of Information Technology Case and Application Research, 12(1), 12-38.

Harrison, T., Pardo, T., Gil-Garcia, J., Thompson, F., \& Juraga, D. (2007). Geographic information technologies, structuration theory, and the world trade center crisis. Journal of the American Society for Information Science \& Technology, 58(14), 2240-2254.

Hussain, Z., \& Cornelius, N. (2009). The use of domination and legitimation in information systems implementation. Information Systems Journal, 19(2), 197-224.

Hussain, Z., Taylor, A., \& Flynn, D. (2004). A case study of the process of achieving legitimation in information systems development. Journal of Information Science, 30(5), 408-417.

Hussenot, A. (2008). Between structuration and translation: An approach of ICT appropriation. Journal of Organizational Change Management, 21(3), 335-347.

Jain, N., Kundu, S., \& Niederman, F. (2008). Offshoring propensity in information technology services: A firm and country level analysis. Management International Review, 48(4), 447-461.

Jandik, T., \& Makhija, A. (2005). Can diversification create value? Evidence from the electric utility industry. Financial Management, 34(1), 61-93. 
Jones, M. (1999). Structuration theory and IT. In W. Currie \& R. Galliers (Eds.), Rethinking management information systems: An interdisciplinary perspective (pp. 103-135). New York, NY: Oxford University Press.

Jones, M., \& Karsten, H. (2008). Giddens's structuration theory and information systems research. MIS Quarterly, 32(1), 127-157.

Jones, M., and Karsten, H. (2009). Divided by a common language? A response to Marshall Scott Poole. MIS Quarterly, 33(3), 589-595.

Jones, M., Orlikowski, W., \& Munir, K. (2004). Structuration theory and information. In J. Mingers \& L. Willcocks (Eds.), Social theory and philosophy for information systems (pp. 297-328). Chichester, UK: John Wiley \& Sons.

Jones, O., Edwards, T., \& Beckinsale, M. (2000). Technology management in a mature firm: Structuration theory and the innovation process. Technology Analysis \& Strategic Management, 12(2), 161-177.

Kelly, S., \& Noonan, C. (2008). Anxiety and psychological security in offshoring relationships: The role and development of trust as emotional commitment. Journal of Information Technology, 23(4), 232-248.

King, W. (2008). Issues in IS offshoring. Information Systems Management, 25(3), 287-289.

Kumar, K., Van Fenema, P., \& Von Glinow, M. (2009). Offshoring and the global distribution of work: Implications for task interdependence theory and practice. Journal of International Business Studies, 40(4), 642-667.

Leonardi, P., \& Bailey, D. (2008). Transformational technologies and the creation of new work practices: Making implicit knowledge explicit in task-based offshoring. MIS Quarterly, 32(2), 411-436.

LeRouge, C., \& Webb, H. (2004). Appropriating enterprise resource planning systems in colleges of business: Extending adaptive structuration theory for testability. Journal of Information Systems Education, 15(3), 315-326.

Mascarenhas, O., Kesavan, R., \& Bernacchi, M. (2006). Lasting customer loyalty: A total customer experience approach. Journal of Consumer Marketing, 23(7), 397-405.

McKinley, W., Zhao, J., \& Rust, K. (2000). A sociocognitive interpretation of organizational downsizing. Academy of Management Review, 25(1), 227-243.

Messner, W. (2011). Offshoring to India-Realising savings and capturing value. Journal of Indian Business Research, 3(1), 63-68.

Miller, D., \& Friesen, P. (1978). Archetypes of strategy formulation. Management Science, 24(9), 921-933.

Mirabal, N., \& DeYoung, R. (2005). Downsizing as a strategic intervention. Journal of American Academy of Business, 6(1), 39-45.

Miranda, S., \& Kim, Y. (2006). Professional versus political contexts: Institutional mitigation and the transaction cost heuristic in information systems outsourcing. MIS Quarterly, 30(3), 725-753.

Mirani, R. (2013). A case study of morphogenetic change in long-term offshoring. International Journal of Information Management, 33(4), 663-673.

Nagasundaram, M., \& Bostrom, R. (1994). The structuring of creative processes using GSS: A framework for research. Journal of Management Information Systems, 11(3), 87-114.

Niederman, F., Briggs, R., de Vreede, G.-J., \& Kolfschoten, G. (2008). Extending the contextual and organizational elements of adaptive structuration theory in GSS Research. Journal of the Association for Information Systems, 9(10), 633-652.

Orlikowski, W. (1992). The duality of technology: Rethinking the concept of technology in organizations. Organization Science, 3(3), 398-427.

Orlikowski, W. (2000). Using technology and constituting structures: A practice lens for studying technology in organizations. Organization Science, 11(4), 404-428.

Orlikowski, W., \& Barley, S. (2001). Technology and institutions: What can research on information technology and research on organizations learn from each other? MIS Quarterly, 25(2), 145-165.

Orlikowski, W., \& Robey, D. (1991). Information technology and the structuring of organizations. Information Systems Research, 2(2), 143-169.

Palvia, S. (2008). Challenges for small enterprises in the sourcing life cycle: Evidence from offshoring to India. Journal of Information Technology Case and Application Research, 10(4), 75-84.

Palvia, S., Palvia, P., Xia, W., \& King, R. (2011). Critical issues of IT outsourcing vendors in India. Communications of the Association for Information Systems, 29(1), 203-220.

Poole, M. (2009). Response to Jones and Karsten, 'Giddens's structuration theory and information systems research'. MIS Quarterly, 33(3), 583-587.

Poole, M., \& DeSanctis, G. (1990). Understanding the use of group decision support systems: The theory of adaptive structuration. In J. Fulk \& C. Steinfeld (Eds.), Organizations and communication technology (pp. 172-193). Newbury Park, CA: Sage 
Porter, M. (1996). What is strategy? Harvard Business Review, 74(6), 61-78.

Pozzebon, M., \& Pinsonneault, A. (2005). Challenges in conducting empirical work using structuration theory: Learning from IT research. Organization Studies, 26(9), 1353-1376.

Ranganathan, C., Krishnan, P., \& Glickman, R. (2007). Crafting and executing an offshore IT sourcing strategy: GlobShops experience. Journal of Information Technology, 22(4), 440-450.

Sawhney, M., Balasubramanian, S., \& Krishnan, V. (2004). Creating growth with services. MIT Sloan Management Review, 45(2), 34-43.

Schwieger, D., Melcher, A., Ranganathan, C., \& Wen, H. (2005). Appropriating electronic billing systems: Adaptive structuration theory analysis. Human Systems Management Journal, 24(1), 1-9.

Simon, J. C., Poston, R. S., \& Kettinger, B. (2009). Creating better governance of offshore services. Information Systems Management, 26(2), 110-122.

Sitlington, H., \& Marshall, V. (2011). Do downsizing decisions affect organisational knowledge and performance? Management Decision, 49(1), 116-129.

Thompson, M. (2012). People, practice, and technology: Restoring Giddens' broader philosophy to the study of information systems. Information and Organization, 22(3), 188-207.

Uzelac, N., \& Sudarevic, T. (2006). Strengthening the link between marketing strategy and financial performance. Journal of Financial Services Marketing, 11(2), 142-156.

Venkatraman, N. (2004). Offshoring without guilt. Sloan Management Review, 45(3), 14-16.

Voelker, T. A. (2011). Kicking up dust: Growth as an irrational market response. Journal of Business Strategies, 28(1), 53-79.

Walsham, G. (2002). Cross-cultural software production and use: A structurational analysis. MIS Quarterly, 26(4), 359-380.

Walsham, G., \& Han, C. (1991). Structuration theory and information systems research. Journal of Applied Systems Analysis, 17, 77-85.

Wilkinson, A. (2005). Downsizing, rightsizing or dumbsizing? Quality, human resources and the management of sustainability. Total Quality Management \& Business Excellence, 16(8), 1079-1088.

Yates, J., \& Orlikowski, W. (1992). Genres of organizational communication: A structurational approach to studying communication and media. Academy of Management Review, 17(2), 299-326. 